\title{
An Appraisal of Groundwater Contamination : A Case Study of Shallow Wells In Agbowo Community, Southwestern Nigeria
}

\author{
Abudulawal L., Apanpa K. A. \\ Department of Geology, The Polytechnic, Ibadan, Nigeria \\ Correspondent Author : apanpaqasim@yahoo.com
}

\begin{abstract}
Abundant as it may seem in Nigeria, access to clean and potable water is a great challenge. Hence the reason for determination of the physico-chemical properties of the groundwater in Agbowo community in Ibadan, Oyo state Southwestern Nigeria for domestic uses. Water samples collected from thirty-four (34) shallow wells with varying depths were subjected to chemical analysis. The water quality parameters were analyzed in accordance to standard methods. The groundwater analysis reviewed includes $\mathrm{pH}$, electrical conductivity, total dissolved solids (TDS), others include $\mathrm{Ca}^{2+}, \mathrm{Mg}^{2+}, \mathrm{K}^{+} \mathrm{Na}^{+}, \mathrm{Fe}^{2+}, \mathrm{NO}_{3}, \mathrm{Cl}^{-} \mathrm{SO}_{4}{ }^{2-}$ and $\mathrm{HCO}_{3}$ - The results indicated that the parameters analyzed have some falling within the limits and some above the maximum permissible limits in accordance to Nigeria Industrial Standard (NIS) and World Health Organization (WHO) guidelines for drinking water. In general, the data revealed that maxima and minima concentrations of the priority physico-chemical water quality parameters examined in the thirty-four (34) water points were mostly within the Target Water Quality Range (TWQR) for domestic use with little exceptions at some points. However, high nitrate concentrations and Total Dissolved Solids (TDS) above the permissible limits in some of the well water sampled are causes for serious concern. Poor construction, lack of maintenance, proximity to sewage tank and stream, as well as indiscriminate dumping of refuse are suggested as the major causes of this development. The overall implication of this observation call for sustenance and improved water resource management strategy for the area in order to prevent the deterioration of the water sources quality, which may pose associated health risks and environmental hazards.
\end{abstract}

Keywords : Physico-chemical properties, Target Water Quality Range, Health risks, Environmental hazards.

\section{INTRODUCTION}

Access to clean water is a human right and a basic requirement for economic development. The safest kind of water supply is the use of groundwater, since it normally has a natural protection against pollution by the covering layers of the earth. Thus, only minor water treatment is required (Reinhard Kirsch 2006).

Groundwater occurrence in a Precambrian Basement terrain is hosted within zone of weathering and fracturing which often are not continuous in vertical and lateral extent (Jeff, 2006). The aquifers of the Basement Complex rocks are the regolith and the fractures in the fresh bedrock which are known to be interconnected at depth (Mohammed, 1984; Alagbe, 1987; Adanu, 1987; Uma and Kehinde, 1994). Water can be an instrument for poverty alleviation, lifting people out of the degradation of having to live without access to safe water and sanitation while at the same time bringing prosperity to all (UNWATER FOR AFRICA, 2004). Oyebade, 1977, noted 
that the priority accorded domestic water supply by the colonial administration had not been sustained by the post independence governments of the country. Although there was a steady increase in the percentage of the total government expenditure spent on water between 1975 and 1992, however there was a $50 \%$ decrease in the total budgetary allocation for water supply between 1992 and 1996 (Areola and Akintola, 1997; Falusi and Gbadegesin, 1998).

After almost sixty years of water supply development in Nigeria, it is regrettable that only $60 \%$ of the population has access to safe drinking water, and in rural areas less than $50 \%$ of the households have access to good potable water (Nigeria Millennium Development Goal Report, 2005). According to Orebiyi et al., 2010, 52\% of Nigerians do not have access to improved drinking water supply. Adequate water resources for future generations are not only regional issue but also a global concern. Just recently, the Federal government of Nigeria declared a state of emergency on Nigeria's water supply, sanitation and hygiene sector while inaugurating the National Action Plan for Revitalization of water supply, Sanitation and Hygiene (WASH). The state of emergency declared has become imperative to reduce the high prevalence of water-borne disease in different parts of the country as Nigeria could not meet the MDG targets for water supply and sanitation that ended in 2015. Besides, the Sustainable Development Goal (SDG) targets for WASH are even more demanding as they require provision of adequate quantity and quality of water at affordable prizes.

In Nigeria, hand-dug wells constitute the largest source of groundwater (Tekwa et al., 2006). Since most of the wells in Ibadan tap their waters from shallow aquifers within the weathered regolith, the examination and determination of their chemical components becomes very important in order to avoid health hazards that may result from the use or consumption of highly polluted water. Ibadan suffers serious water supply problems: cases of dry taps are common in virtually every part of the city. A sight of children/women searching for water is a common experience (Ifabiyi, 2008). Potable water is the water fit for human consumption, it does not contain chemical substances or microorganisms in amount that can cause hazards to health (Alonge, 2005). Water must be substantially free of dissolved salt, plants, animal waste and bacterial contamination to be suitable for human consumption.

This study is necessitated due to incessant water supply and by the fact that the study area is largely occupied by students and staff of the University of Ibadan and The Polytechnic, Ibadan as well as other local occupants, and thus complement the effort of the Federal Government of Nigeria to achieve the SDG targets for WASH by 2030. The area is one of the largest communities in Ibadan North, southwestern Nigeria (Fig 1). Ibadan North has a population of 306,795 (NPC, 2006) making it densely populated area. Adetunji and Odetokun (2011), while assessing Groundwater conta- mination in Agbowo community, Ibadan Nigeria, observed that Total Aerobic Bacteria Counts (TABC) and Total Coliform Counts (TCC) exceeded the international standard of 0 per $100 \mathrm{~mL}$ of potable water and concluded that there is a need to set standards for the siting of wells from septic tanks while considering all possible sources of well contamination.

The present work presents a physico-chemical approach as means of providing additional information on the hydrological investigations and thus assessing the purity variation of the groundwater in the study area, thus ascertaining the source of pollution. The study area is located between latitude 
$7^{0} 26^{\prime} .446^{1} \mathrm{~N}$ and $7^{0} 26^{\prime} .879^{1}$, and longitude $3^{0} 54^{\prime}$ $453^{1} \mathrm{E}$ and $3^{0} 55^{\prime} 069^{1}$.

\section{Geologic and Hydrogeologic Settings}

The study area, Agbowo and its environs, is within the basement complex rock of Ibadan, Nigeria. According to Rahaman (1976), basement complex rocks of Ibadan can be classified into major and minor type. The major rock in the study area is banded gneiss with local schist and quartzite (fig. 2). These rocks in most places are covered by weathered regolith. The banded gneiss covers most places in the study area. The Gneisses are strongly foliated, thus the description 'banded', with a general strike of NE, NW-SE direction. The alternating light and dark coloured bands often splits into two or more bands with quartzo-feldspathic minerals alternating with ferromagnesian minerals. Banded gneiss in the study area is predominantly medium grained. It is made up of minerals like quartz, biotite, plagioclase, chlorite and opaque minerals. These rocks are considered unsuitable for accumulation of groundwater unless they are fractured or jointed.

Weathering, especially in the tropic is the dominant process in the development of superficial rocks. The rate of weathering depends on the groundwater flow, which is very effective in the saturated lower part of the weathering profile. The fracture also exposed fresh crystalline surfaces to weathering activities of the basement rocks. Water levels, in the wells fluctuate according to the season. The recharge to the water table is directly from precipitation in the surface and from stream flowing in the area. The non-occurrence of inhomogeneous rock type such as pegmatite and quartz veins in the study area have been observed to be the major reason for low water yield. This is due to fineness of the grain, and the low susceptibility to weathering of some of the components minerals in gneisses.

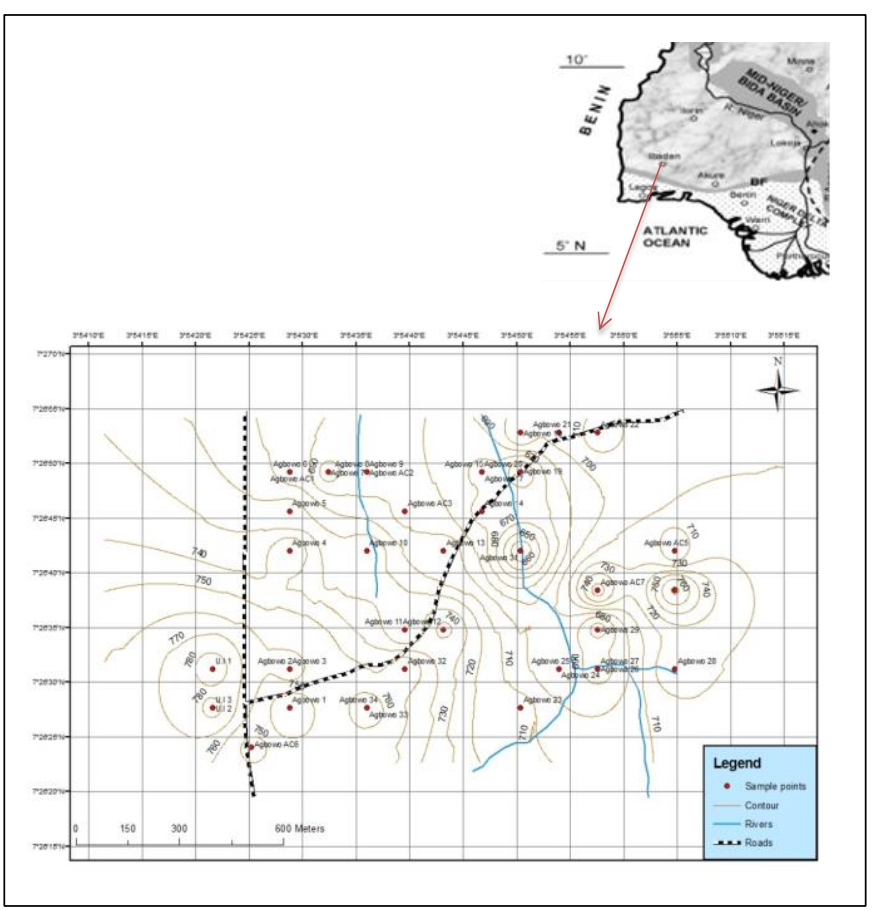

Fig. 1: Location map of the study area. The insert shows Southwestern Nigeria

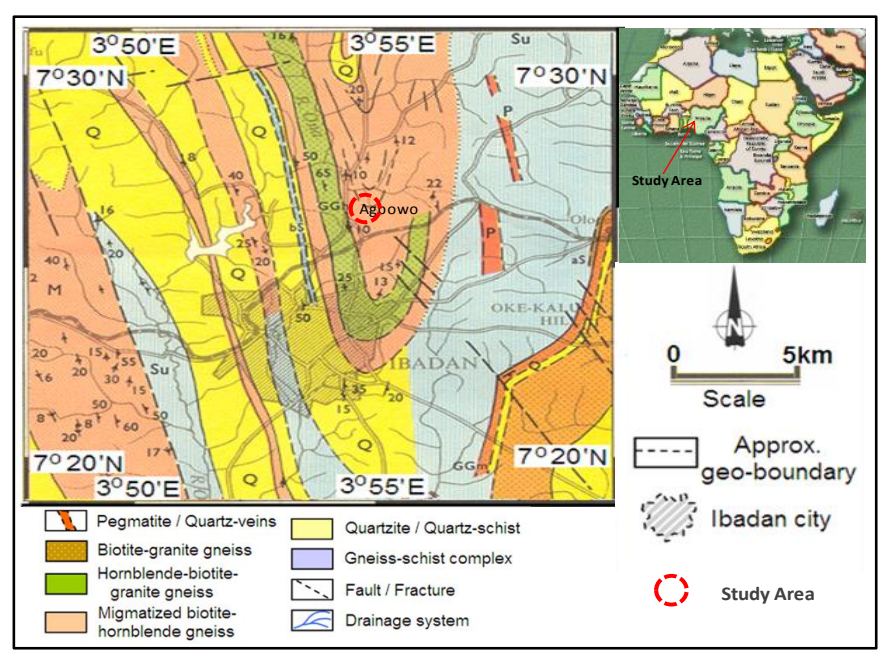

Fig. 2: Geological Map of Ibadan showing the study area (Adapted from NGSA, 2006)

\section{METHODS AND MATERIAL}

The field sampling was carried out during the wet season. Water samples were collected from thirty- 
four water points, all from shallow hand dug wells. The temperature, total depth of wells, and depths to water level were taken and recorded. The water column thickness was obtained as the difference between the total depth of wells and depth to water level. In order to avoid contamination from the use of reactive or metallic containers, a clean rubber container was used in drawing water from the wells. Samples were stored in clean sterilized plastic water bottles and labeled for easy identification. The raw water samples and control were taken to the International Institute of Tropical Agriculture (IITA), Ibadan laboratory and analyzed for the following components: $\mathrm{K}^{+}, \mathrm{Na}^{2+}, \mathrm{Mg}^{2+}, \mathrm{Ca}^{2+}, \mathrm{Fe}^{2+}, \mathrm{NO}_{3}, \mathrm{HCO}_{3}$, $\mathrm{SO}_{4}{ }^{2-}, \mathrm{Cl}, \mathrm{P}^{\mathrm{H}}, \mathrm{TDS}$, conductivity and Temperature. The anions and the cations in the sample were determined using Atomic Absorption Spectrometer, while the physical parameters measured include $\mathrm{pH}$, TDS, EC and Temperature were determined using Mi 806 MARTINI Combined meter.

\section{Results and Discussion}

The average concentrations of analyzed physicochemical parameters compared to quality standards for drinking water are presented in table 1. The results of the physical parameters conducted in-situ and chemical analysis are presented in table 2, and 3 respectively.

\section{Physical Investigations}

The physical parameters examined include temperature $\left({ }^{\circ} \mathrm{C}\right), \mathrm{pH}$, total dissolves solids $(\mathrm{mg} / \mathrm{l})$, conductivity (Us/cm), total depth $(\mathrm{m})$, depth to water level $(\mathrm{m})$ and the thickness of water column (m) elevation ( $\mathrm{ft}$ ) and coordinates. There is wide range of values recorded for various physical parameters measured. The total depth of each well represents the level to which. it was dug. The shallowest well was Agbowo 022 with total depth of $1.90 \mathrm{~m}$, and the deepest well encountered at Agbowo 033 with total depth of $8.82 \mathrm{~m}$. The average water well depth in the area is $4.49 \mathrm{~m}$. The water level represents the level of water in the wells and this is equivalent to the water table of the environment. The depth to water level ranges from $0.19 \mathrm{~m}$ (Agbowo 19) to $7.15 \mathrm{~m}$ at (Agbowo 033) with average of $1.79 \mathrm{~m}$. Water column thickness range from $0.35 \mathrm{~m}$ (Agbowo 30) to $6.04 \mathrm{~m}$ (Agbowo 003) with average of $2.69 \mathrm{~m}$. The appreciable water column thickness obtained is an indication of good recharge rate.

The temperature of the water samples collected in the studied area is fairly constant. It ranges from 26.500C to 28.20C (Agbowo 25 to Agbowo13) with an average of $27.60 \mathrm{C}$. The low temperature value experienced at Agbowo 25 could be related to its shallow depth, since the law of hydrothermal gradient states that temperature increases with depth. Thus the relative high temperature value experienced at Agbowo 13 could also be related to it is relatively deeper depth. The graphical correlation of well depth against temperature is shown in figure 3 .

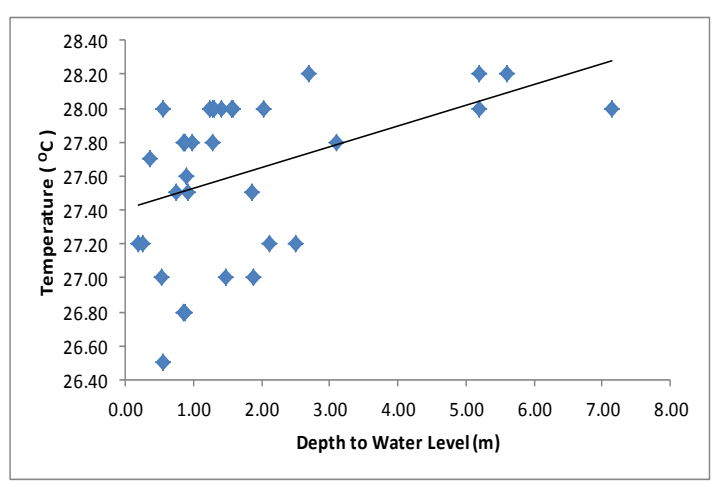

Fig. 3: Well depth against temperature

The $\mathrm{pH}$ of water sample collected ranges from 7.6 (Agbowo 30) to 8.8 (Agbowo 13, 15, 20, 28, and 29) with an average of 8.5 . The $\mathrm{pH}$ value of most groundwater is controlled by the amount of dissolved CO2 gas and the dissolved carbonates and 
bicarbonates in the mineral salt. The CO2bicarbonate relation is the principal control of $\mathrm{pH}$ in most groundwater (Bollenbach, 1975). Drinking water with $\mathrm{pH} 6.5$ and 8.5 is generally considered satisfactory by WHO 2011; NIS, 2007.

Conductivity gives an indication of amount of ions in the water. The conductivity value ranges from 590us/cm (Agbowo 005) to $1831 \mathrm{us} / \mathrm{cm}$. (Agbowo 27) with an average of $1126.90 \mathrm{us} / \mathrm{cm}$. This value is higher when compare to $1000 \mathrm{us} / \mathrm{cm}$, the maximum value recommended by WHO, 2011; and NIS 2007 for drinking water. In solution as dilute as most groundwater, the specific conductance varies directly with the amount of dissolved minerals in the water (Bollenbach, 1975). Waters with relatively high specific conductance can cause corrosion of iron and steel (Hem, 1959; Hem and Cropper 1959).

The Total Dissolve Solids (TDS) concentration in water is a general indication of the overall suitability of water for many uses. The value of TDS ranging from 286mg/l (Agbowo 005) to 908mg/l (Agbowo 027) with an average of $563.21 \mathrm{mg} / \mathrm{l}$. This is contrary to $500 \mathrm{mg} / 1$ maximum value recommended by WHO 2011 and NIS 2007, and this may result in adverse taste effects. It is recommended that water containing more than $500 \mathrm{mg} / 1$ of dissolved solids not be used if other less mineralized supplies are available. The graphical correlation of TDS against EC, and Calcium concentration against TDS is shown in figure 4 and 5 respectively.

\section{RESULTS AND DISCUSSION}

The average concentrations of analyzed physicochemical parameters compared to quality standards for drinking water are presented in table 1 . The results of the physical parameters conducted in-situ and chemical analysis are presented in table 2 , and 3 respectively.

\section{Physical Investigations}

The physical parameters examined include temperature $(\mathrm{oC}), \mathrm{pH}$, total dissolves solids $(\mathrm{mg} / \mathrm{l})$, conductivity $(\mathrm{Us} / \mathrm{cm})$, total depth $(\mathrm{m})$, depth to water level $(\mathrm{m})$ and the thickness of water column (m) elevation ( $\mathrm{ft}$ ) and coordinates. There is wide range of values recorded for various physical parameters measured. The total depth of each well represents the level to which it was dug. The shallowest well was Agbowo 022 with total depth of $1.90 \mathrm{~m}$, and the deepest well encountered at Agbowo 033 with total depth of $8.82 \mathrm{~m}$. The average water well depth in the area is $4.49 \mathrm{~m}$. The water level represents the level of water in the wells and this is equivalent to the water table of the environment. The depth to water level ranges from $0.19 \mathrm{~m}$ (Agbowo 19) to $7.15 \mathrm{~m}$ at (Agbowo 033) with average of $1.79 \mathrm{~m}$. Water column thickness range from $0.35 \mathrm{~m}$ (Agbowo 30) to $6.04 \mathrm{~m}$ (Agbowo 003) with average of $2.69 \mathrm{~m}$. The appreciable water column thickness obtained is an indication of good recharge rate.

The temperature of the water samples collected in the studied area is fairly constant. It ranges from 26.500C to 28.20C (Agbowo 25 to Agbowo13) with an average of $27.60 \mathrm{C}$. The low temperature value experienced at Agbowo 25 could be related to its shallow depth, since the law of hydrothermal gradient states that temperature increases with depth. Thus the relative high temperature value experienced at Agbowo 13 could also be related to it is relatively deeper depth. The graphical correlation of well depth against temperature is shown in figure 3 . 


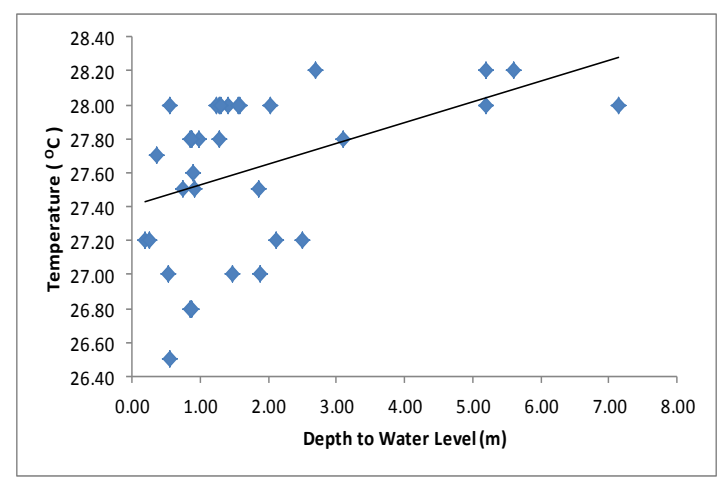

Fig. 3 : Well depth against temperature

The $\mathrm{pH}$ of water sample collected ranges from 7.6 ( Agbowo 30) to 8.8 (Agbowo 13, 15, 20, 28, and 29) with an average of 8.5. The $\mathrm{pH}$ value of most groundwater is controlled by the amount of dissolved CO2 gas and the dissolved carbonates and bicarbonates in the mineral salt. The CO2bicarbonate relation is the principal control of $\mathrm{pH}$ in most groundwater (Bollenbach, 1975). Drinking water with $\mathrm{pH} 6.5$ and 8.5 is generally considered satisfactory by WHO 2011; NIS, 2007.

Conductivity gives an indication of amount of ions in the water. The conductivity value ranges from 590us/cm (Agbowo 005) to $1831 \mathrm{us} / \mathrm{cm}$. (Agbowo 27) with an average of $1126.90 \mathrm{us} / \mathrm{cm}$. This value is higher when compare to $1000 \mathrm{us} / \mathrm{cm}$, the maximum value recommended by WHO, 2011; and NIS 2007 for drinking water. In solution as dilute as most groundwater, the specific conductance varies directly with the amount of dissolved minerals in the water (Bollenbach, 1975). Waters with relatively high specific conductance can cause corrosion of iron and steel (Hem, 1959; Hem and Cropper 1959).

The Total Dissolve Solids (TDS) concentration in water is a general indication of the overall suitability of water for many uses. The value of TDS ranging from 286mg/l (Agbowo 005) to 908mg/l (Agbowo 027) with an average of $563.21 \mathrm{mg} / \mathrm{l}$. This is contrary to $500 \mathrm{mg} / 1$ maximum value recommended by WHO 2011 and NIS 2007, and this may result in adverse taste effects. It is recommended that water containing more than $500 \mathrm{mg} / \mathrm{l}$ of dissolved solids not be used if other less mineralized supplies are available. The graphical correlation of TDS against EC, and Calcium concentration against TDS is shown in figure 4 and 5 respectively.

\section{Chemical Investigations}

In order to determine the portability of shallow well water in Agbowo and its environs, major constituents in water such as bicarbonate, sulphate, chloride, calcium, sodium and magnesium are chemically analyzed. The minor constituents also determined include nitrate, potassium and iron. These constituents are analyzed, average concentration were determined and then compared with World Health Organization (WHO) and Nigeria Industrial standards.

Table 1: Showing average concentrations of analyzed physico-chemical parameters compared to quality standards for drinking water.

\begin{tabular}{|c|c|c|c|}
\hline $\begin{array}{l}\text { Chemical } \\
\text { Parameters } \\
\text { Analysed }\end{array}$ & $\begin{array}{c}\text { NAFDAC } \\
2007\end{array}$ & $\begin{array}{l}\text { WHO } \\
2007\end{array}$ & $\begin{array}{c}\text { Mean Conc. } \\
\text { obtained }\end{array}$ \\
\hline $\mathrm{Ph}$ & $6.5-8.5$ & $\ldots$ & 8.5 \\
\hline Temp. ${ }^{\circ} \mathrm{C}$ & $\ldots$ & $\ldots$ & $\ldots$ \\
\hline Cond. (us/cm) & 1000 & 1000 & 1126.9 \\
\hline $\operatorname{TDS}(\mathrm{Mg} / 1)$ & 500 & 500 & 562.9 \\
\hline $\mathrm{Na}^{+}(\mathrm{Mg} / \mathrm{I})$ & $\ldots$ & 200 & 113 \\
\hline $\mathrm{Mg}^{+}(\mathrm{Mg} / \mathrm{I})$ & $\ldots$ & 20 & 0.66 \\
\hline $\mathrm{K}^{+} \quad(\mathrm{Mg} / \mathrm{I})$ & 10 & 12 & 2.13 \\
\hline $\mathrm{Ca}^{+}(\mathrm{Mg} / \mathrm{I})$ & 75 & 100 & 113 \\
\hline $\mathrm{Fe}^{2+}(\mathrm{Mg} / \mathrm{I})$ & 0.3 & 0.3 & 0.1 \\
\hline $\mathrm{Cl}^{-} \quad(\mathrm{Mg} / \mathrm{I})$ & 100 & 200 & 38.1 \\
\hline $\mathrm{NO}_{3}{ }^{2-}(\mathrm{Mg} / \mathrm{I})$ & 10 & 50 & 40.19 \\
\hline $\mathrm{SO}_{4}{ }^{2-}(\mathrm{Mg} / 1)$ & 100 & 100 & 20.3 \\
\hline $\mathrm{CO}_{3}^{-}(\mathrm{Mg} / \mathrm{I})$ & $\ldots$ & $\ldots$ & 34.23 \\
\hline
\end{tabular}




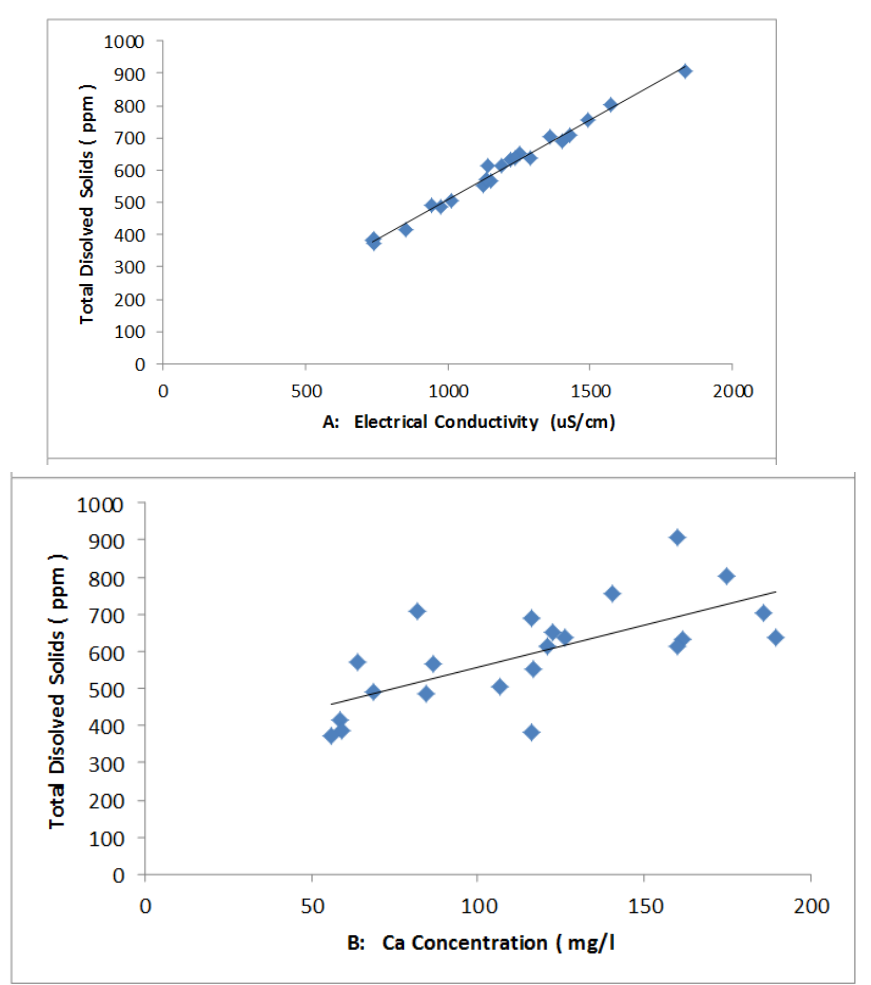

Fig. 4 and 5: Total dissolved solid (ppm) against electrical conductivity and Calcium concentration (mg/l) respectively

Bicarbonate is the most abundant anion in the study area, having concentration ranging from $53.4 \mathrm{mg} / \mathrm{l}$ to $184.6 \mathrm{mg} / \mathrm{l}$ with an average of $110.59 \mathrm{mg} / \mathrm{l}$. The bicarbonate (HCO3-) is the principal alkaline constituent in almost all water supplies. Bicarbonate alkalinity is introduced into the water by $\mathrm{CO} 2$ (carbon dioxide) dissolving carbonate containing minerals. Bicarbonate stability in water however, depends on the $\mathrm{pH}$ of the water, usually for values between 5 and 7 (Taylor, 1958).

Sulphate occurs in almost all natural water. The concentration of sulphate (SO42) in the samples ranges from $11.9 \mathrm{mg} / 1$ to $40.0 \mathrm{mg} / \mathrm{l}$ with the average of $20.34 \mathrm{mg} / \mathrm{l}$. This value is within the NIS allowable limits. High concentration of sulphate in drinking water causes laxative effect when combined with calcium and magnesium, the two most common component of hardness. The major source of the sulphate ions in the water is believed to be sulphate ions recycled from the atmosphere through rain percolation (Davies and Dewiest, 1966). Sulphates in groundwater may also be derived from dissolution of anhydrite or gypsum, it may also come from the oxidation of pyrite (Bollenbach, 1975)

The chloride concentration in the water sample range from $17.7 \mathrm{mg} / \mathrm{l}$ to $69.2 \mathrm{mg} / \mathrm{l}$ with an average of $38.07 \mathrm{mg} / \mathrm{l}$. The result of the analysis shows that the average concentration of chloride ions falls within the recommended limits of NIS 2007 which is $250 \mathrm{mg} / 1$. Sources of chloride in water often include magmatic rocks, fertilizer human excrement (especially in the area where the wells are very close to the toilets). (Freeze and Cherry, 1979). It is also believed that igneous rocks are generally low in chloride. Water with greater than 250ppm chloride concentration is generally objectionable for municipal purposes. However, chloride content of greater than $350 \mathrm{ppm}$ is said to be objectionable for most irrigation or industrial uses by some authors. Water with greater than or equal to 500ppm chloride is found to have disagreeable taste (Bollenbach, 1975). Calcium concentration in the water samples collected ranges from $55.90 \mathrm{mg} / \mathrm{l}$ to $189.57 \mathrm{mg} / \mathrm{l}$ with an average of $113.12 \mathrm{mg} / / \mathrm{l}$. About $79.3 \%$ of the sampled water has concentration below the standard of $150 \mathrm{mg} / \mathrm{l}$ (NIS 2007) which is the maximum allowable limits. About six locations representing 20.7\% however contain calcium concentration above the maximum allowable limit. Calcium concentration is found to be higher than other cations analyzed. Calcium and magnesium cause almost all the hardness of water. The metallic calcium and magnesium ions and the corresponding bicarbonate, sulfate, chloride and nitrate from these dissolved compounds will be found in solution. The bicarbonate ions exist in groundwater as the result of dissolved carbon-dioxide. 
The CO2 helps the water to dissolve carbonate minerals with which it comes in contact (Bollenbach, 1975).

Sodium does not contribute to hardness of water. It is however stressed that groundwater containing considerable sodium carbonate or sodium bicarbonate are alkaline and may have $\mathrm{pH}$ values of 9 or more. Its concentrations in the samples ranges from $9.98 \mathrm{mg} / \mathrm{l}$ to $170.33 \mathrm{mg} / \mathrm{l}$ with average of $112.88 \mathrm{mg} / \mathrm{l}$. Its value is within the acceptable limit of the NIS 2007. The possible source of $\mathrm{Na}+$ in the water are weathered plagioclase feldspars, atmospheric dust washed down by rain, especially wet season, and exchangeable sodium ions from clays.

The concentration of magnesium in the water sample collected ranges from $0.31 \mathrm{mg} / 1$ to $1.14 \mathrm{mg} / 1$ with an average value of $0.66 \mathrm{mg} / \mathrm{l}$. All the sampled locations have magnesium concentration higher than the allowable limits of $0.20 \mathrm{mg} / \mathrm{l}$ (NIS, 2007). The probable source of magnesium in water is weathering of feldspar and mica, and other related mineral hosted by the basement rocks in the area. Besides, the role of percolating water especially in the wet season as a participant in the chemical reaction or alteration usually results in the leaching of cations in the silicate minerals (Malomo, 1990). There is no health complication for magnesium except consumer's acceptability.

The safe nitrate limit for domestic water is set at $50 \mathrm{mg} / \mathrm{l}$ by NIS (2007). The nitrate concentration in the samples collected ranges from $19.21 \mathrm{mg} / \mathrm{L}$ to $61.98 \mathrm{mg} / \mathrm{l}$ with the average of $40.19 \mathrm{mg}$. Nitrate in many groundwater appear to be unrelated to any geologic formation. Nitrate is one of the most common groundwater contaminants. However, some authorities believe that Nitrate occurs naturally in soil and water as a result of decaying plant and animal residue. Other common sources of nitrate include human sewage and livestock manure. Nitrate is also a common constituent of chemical fertilizer. The graphical correlation of Nitrate concentration against well depth is shown in figure 6. Nitrate concentration higher than $45 \mathrm{ppm}$ is undesirable and toxic on young infants. Nitrate in drinking water causes cyanosis, and asphyxia (blue-baby "syndrome") in infants under 3 months (WHO, 1984; 1997).

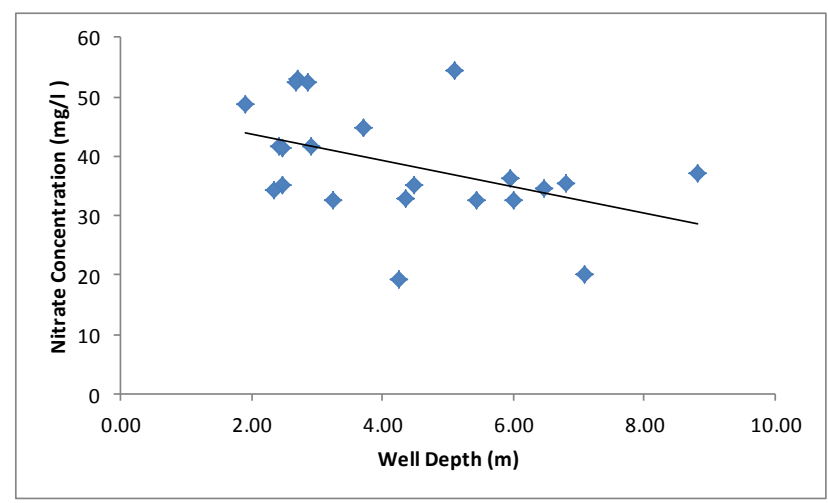

Figure 6: Nitrate concentration (mg/l) against Well Depth (m)

The behaviour of Potassium and Sodium is similar. Nearly all their compounds are soluble so that Sodium leached from rocks or soils remain in solution (Bollenbach, 1975). The water samples analyzed has potassium range from $0.35 \mathrm{mg} / \mathrm{l}$ to $4.89 \mathrm{mg} / \mathrm{l}$ with an average of $2.13 \mathrm{mg} / \mathrm{l}$. Although excessive intake may have a laxative effect, public health authorities have not established a maximum limits. The major source of Potassium in water is weathered Orthoclase and Microcline feldspar.

Potassium migration is not stable in groundwater due to it is ready exchange with sodium in clays (freeze and cherry 1979). This is an important contributor to water hardness. When water is heated, it breakdown and precipitate out of solution, forming scale. 
Iron is common in many igneous rocks and it is found in trace amounts in practically all sediments and sedimentary rocks. The specific form of iron intake in water depends on the amounts of oxygen concentration in the water, and the $\mathrm{pH}$. Iron has concentration ranging from $0.04 \mathrm{mg} / \mathrm{l}$ to $0.12 \mathrm{mg} / \mathrm{l}$ with the average $0.1 \mathrm{mg} / \mathrm{l}$. The source of iron may be related to the production of iron oxides alongside with clay minerals. Iron in concentration greater than $0.3 \mathrm{mg} / 1$ which is the maximum value permitted by NIS 2007, may cause brown and black stains in laundry, plumbing fixtures and sinks. USPHS suggests that the iron content in groundwater should not be greater than $0.3 \mathrm{ppm}$. Water standing in a well that has been idle will have higher iron content than the natural water in the aquifer (Bollenbach, 1975).

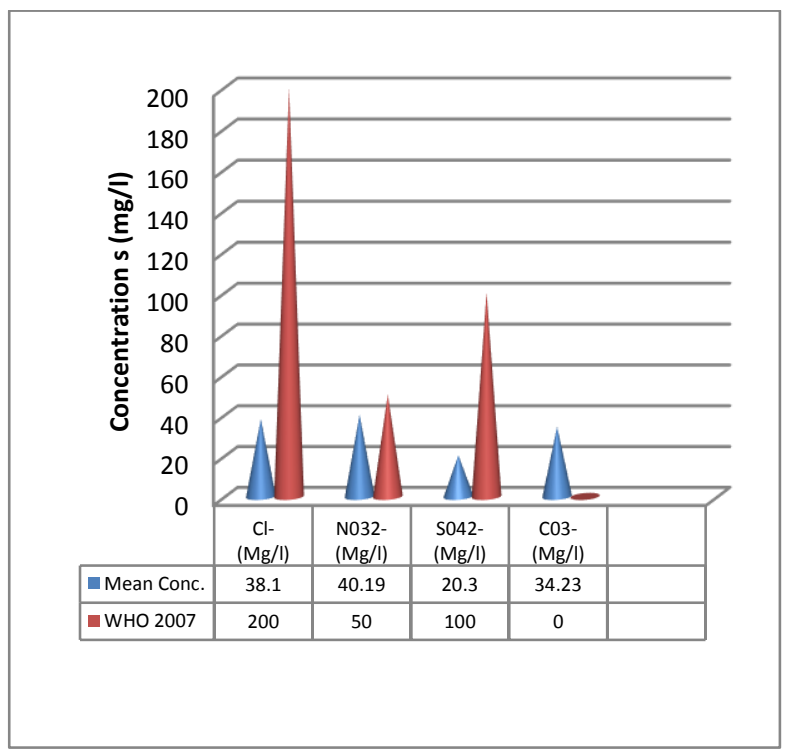

Figure 7: Histogram depicting mean concentration of cations compared to WHO standards

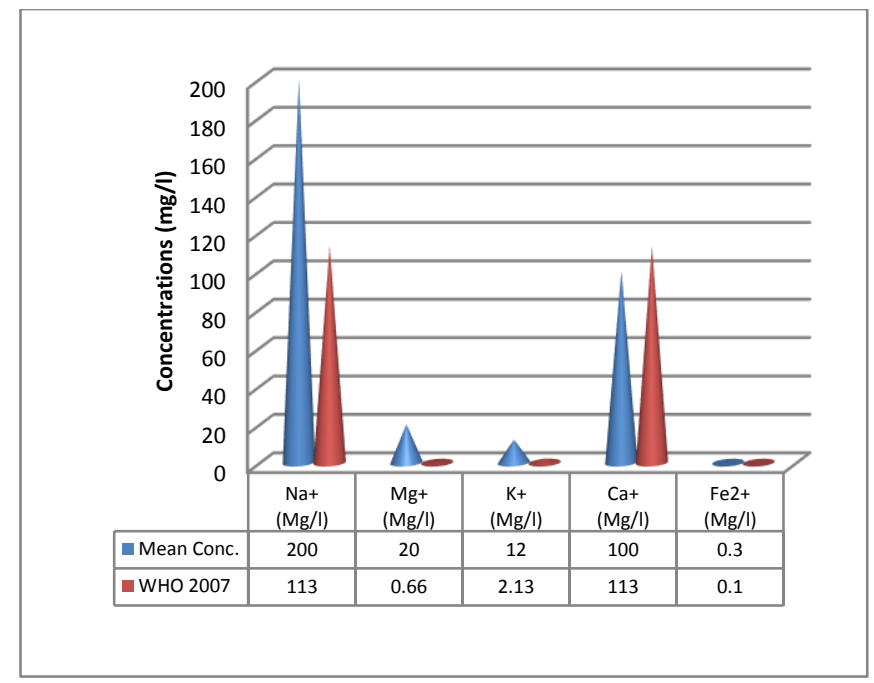

Figure 8: Histogram depicting mean concentrations of anions compared to WHO standards

\section{CONCLUSION}

There primary purpose of a water analysis is to determine the suitability of water for a purposed use. The three main classes of use are domestic (household), agriculture and industrial. Agbowo and its environs in the Ibadan north local government is dominated by staff and students of both university of Ibadan and the Polytechnic, Ibadan as well as other community members. Thus, the use of water in this area is strictly domestic. Since there is no public water system, a system for the provision of the public of piped water for human consumptions, people living in the area depend on groundwater through construction of shallow wells and occasionally deep water boreholes.

The physico-chemical investigation of shallow well water in the area shows that some shallow wells in the environs are unkempt and wrongly positioned and this has resulted in concentrations of some major parameters above the allowable limits and thus rendered the well water not suitable for drinking and household use. Only few locations met up with the 
standards. High concentration of nitrate, magnesium, as well as total dissolved solids and electrical conductivity in many of the sampled locations are major cause for concern.

Poor construction, lack of maintenance, proximity to sewage tank and stream are some of the major causes of this development. In conclusion, government intervention in collaboration with the inhabitants of the area is highly necessary to provide clean and safe water for household use. Proper dissemination of information on construction of shallow wells and water treatment should be given a priority to prevent outbreaks of epidemic in the area.

\section{RECOMMENDATION}

The following recommendation could be useful to proffer a long-lasting solution to the common lack of potable water in the area if given a cognizance:

- Infiltration of surface water should be prevented while constructing water wells. The last $3 \mathrm{ft}$ to the surface should be cased off with concrete plugs.

- Water wells should always be properly covered with wells lids. This will prevent settling of dust and other contaminants in well water.

- The inhabitants of the Ibadan North Local Government should be sensitized on the possible side effects of unhygienic condition of living.

- People should also be educated on the merits of regular water treatments, and hence the prescription of necessary treatment measure.

- There is a need to set standards for the siting of wells from septic tanks while considering all possible sources of well contamination.

Table 2: Field Measurements
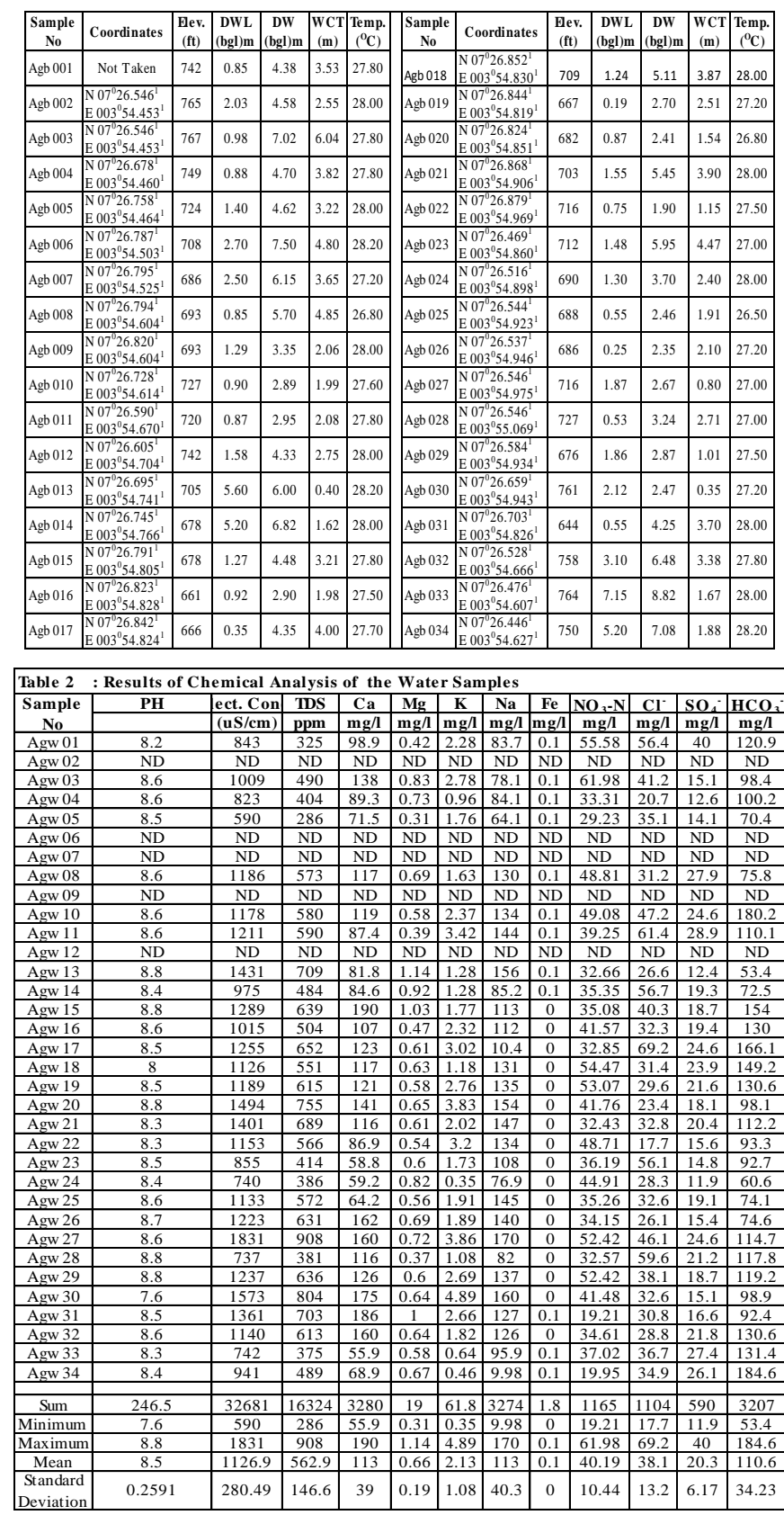

\section{REFERENCES}

[1]. Adanu E.A. (1994). "Groundwater Development and Management in the Basement Complex Terrain in Zaria, Kaduna Area "Water Resources 4(1\&2): 64- 68.

[2]. Adetunji V. O. and Odetokun I. A. (2011). Groundwater contamination in Agbowo community, Ibadan Nigeria: Impact of septic 
tanks distances to wells. Malaysian Journal of Microbiology, Vol 7(3) 2011,pp. 159-166

[3]. Akintola, F.O., Areola O., and Faniran A. (1980). "The Elements of Quality and Social Costs in Rural Water Supply and Utilization". Water Supply and Management, vol.4, pp 275 282.

[4]. Alagbe, S. A. (2006). Preliminary evaluation of hydrochemistry of the Kalambaina Formation, Sokoto Basin, Nigeria. Environ. Geol., 51: 3945.

[5]. Alagbe S. A. (1987). Hydrogeology of the river Kanjimi catchment area, kaduna state. Unpubl. M.Sc. Thesis, Dept of Geology, A.B.U Zaria. P 168.

[6]. Alonge, D.O. (2005). Potable water; Meat and Milk Hygiene. Alfas Press Nig. Company, Ibadan, Nigeria. pp. 32-43.

[7]. Areola, O. and Akintola, F. O. (1997). "Manpower and Institutional Constraints on Urban Water Supply in Nigeria: A Case Study of the Northwest Zone" Geo Journal 43:p. 125133

[8]. Bollenbach (1975). "Groundwater and wells" published by Johnson Division UDP Inc. Saint Paul, Minnesota, 55165. Pp 65 - 80.

[9]. Davies, and Dewiest, (1966). Hydrogeology. John Wiley and sons New York, 463p Falusi, A. O., and A. Gbadegesin (1998). "Dependency and subsidy in the provision of water for domestic agricultural and industrial uses: implications for sustainable development and quality of life".

[10]. Freeze RA, Cherry JA (1979). Groundwater. 2nd edn. Prentice Hall, Eaglewood, Cliff, New Jersey, USA, p. 604.

[11]. Hem J. D. (1959). Study and Interpretation of the Chemical Characteristics of Natural Water. Water Supply Paper 1473 (1959) pp 254, US. Geological Survey, Washington D.C.
[12]. Hem, J. D. and Cropper, W. H. (1959). A survey of ferrous-ferric chemical equi- libria and redox potentials: U.S. Geol. Survey Water-Supply Paper 1459-A

[13]. Ifabiyi, I. P. (2008). "Depth of Hand Dug Wells and Water Chemistry:

[14]. Example from Ibadan Northeast Local Government Area, Oyo State, Nigeria, Journal of Social Sciences, Vol. 17 Issue 3 pp-261-266.

[15]. Jeff D. (2006). "Forum for groundwater" htt://www.waternet.co.za/groundwater/(3) December 2006.

[16]. .Malomo, S., Okufarasin, V.A. and Olorunniwo M.A.(1990). Groundwater chemistry of weathered zone aquifers of an area underlain by basement complex rocks. Journal of African Earth Sciences (and the Middle East). Volume 11, Issues 3-4, 1990, Pages 357-371

[17]. Mohammed I (1984). Hydraulic properties of the Basement Complex and Chad Formation aquifers of Kano State based on test- pumping of selected boreholes. M.Sc. Thesis, Dept. Geol., Ahmadu Bello University, Nigeria.

[18]. National Population Census (2006): Federal Republic of Nigeria Official Gazette Legal Notice on Publication of the details of breakdown of the National and State Provisional Totals. National Bureau of Statistics Official Gazette (FGP 71/52007/2,500(OL24) Abuja. URL http://www.nigerianstat.gov.ng

[19]. Nigerian Geological Survey Agency (NGSA) (2006). Systematic Geologic Mapping of the Nigerian States by Nigerian Geological Survey Agency, 2006.

[20]. Nigerian Industrial Standards (NIS). (2007) Nigerian Standard for Drinking Water Quality, Approved by Standard Organization of Nigeria, NIS 554, ICS 30.060.20.

[21]. Nigeria Millenium Development Goals 2005 Report. 
[22]. Orebiyi, E. O., Awomeso, J. A., Idowu, O. A., Martins, O., Oguntoke, O. and Taiwo, A. M. (2010). Assessment of pollution hazards of shallow well water in Abeokuta and Environs, Southwest, Nigeria. American Journal of Environmental Sciences 6(1), 50- 56.

[23]. Oyebade, L. 1977. Urban Water Resources Development In Nigeria. Hydrological Report, Federal Ministry of the Water Resources, Lagos, Nigeria.

[24]. Rahaman M.A. (1976): Review of the Basement Geology of South Western Nigeria in Geology of Nigeria C.A.,Kogbe, Elizabethan Publicating Company, Lagos, Nigeria pp. 41-58.

[25]. Reinhard Kirsch (2006). Groundwater Geophysics: A tool for Hydrogeology. SpringerVerlag Berlin Heidelberg 2006, XVII, 493 p, 300 illus. 3-540-29383-3. Berlin: Springer, 2006.Edition Number 1, Germany.

[26]. Standards Organization of Nigeria (SON) 2007. Nigeria Standards for Drinking Water Quality, Nigerian Industrial Standard (NIS 554), 15-20.

[27]. Tekwa, I.J., Abba, M.U., Ray, H.H. (2006). An Assessment of Dug-well water quality and uses in Mubi, Nigeria. Journal of Sustainable Development in Agriculture and Environment, vol. 2(1): p 1 - 5 .

[28]. Taylor, E.W., 1958. The Examination of Water and Water Supplies. Church Hill Ltd., Press, pp: 330 .

[29]. Uma K.O. and Kehinde M.O. (1994)."Potentials of regolith Aquifers in relation to Water Supplies to rural Communities: A case study from parts of Northern Nigeria" journal of Mining and Geology 30 (1): 97-109

[30]. UNITED NATIONS WATER FOR AFRICA (2004): A Gender Perspective on Water Resources and Sanitation. Submitted by: Interagency Task Force on Gender and Water.
Commission on Sustainable Development. Twelfth Session, 14-30 April 2004. New York

[31]. WHO (World Health Organization) (1984). Guidelines for drinking water quality. Vol. 2, Health criteria and other supporting information, WHO Publ. Geneva, p. 335.

[32]. WHO (World Health Organization) (1997); Basic Environmental Health, WHO, Geneva Switzerland 2nd edition 3

[33]. WHO (2011): Guidelines for Drinking Water Quality, fourth edition. WHO Press, World Health Organization, 20 Avenue, Appia, 1211 Geneva, 21 Switzerland.

\section{Cite this article as :}

Abudulawal L., Apanpa K. A., "An Appraisal of Groundwater Contamination : A Case Study of Shallow Wells In Agbowo Community, Southwestern Nigeria", International Journal of Scientific Research in Science and Technology (IJSRST), Online ISSN : 2395-602X, Print ISSN : 2395-6011, Volume 6 Issue 4, pp. 104-115, July-August 2019. Available at doi : https://doi.org/10.32628/IJSRST196417 Journal URL : http://ijsrst.com/IJSRST196417 